\title{
PENGARUH CORE STABILITY EXERCISE TERHADAP PENINGKATAN KEKUATAN TOGOK DAN KESEIMBANGAN DINAMIS ATLET
}

\section{Oleh:}

Agung Muladi dan BM. Wara Kushartanti

\section{Jurusan Pendididkan Kesehatan dan Rekreasi FIK UNY}

\section{Abstrak}

Penelitian ini bertujuan untuk mengetahui pengaruh core stability exercise terhadap peningkatan kekuatan togok dan keseimbangan dinamis atlet UKM Pencak Silat UNY.

Penelitian ini merupakan penelitian pre-experimental dengan rancangan one group pretest-posttest design. Lokasi penelitian di GOR dan Hall Beladiri Universitas Negeri Yogyakarta. Populasi dalam penelitian ini adalah atlet UKM Pencak Silat Universitas Negeri Yogyakarta yang berjumlah 40 orang. Jumlah sampel dalam penelitian ini ditentukan menggunakan perhitungan rumus Slovin. Berdasarkan perhitungan ditentukan jumlah sampel sebanyak 20 orang. Teknik pengambilan sampel dalam penelitian ini menggunakan random sampling yang diambil secara acak dari 22 orang yang masuk kriteria inklusi dan eksklusi. Latihan diberikan 3 kali per minggu selama 16 kali pertemuan. Instrumen yang digunakan untuk mengukur kekuatan togok menggunakan back dynamometer dengan validitas 0,82 dan reliabilitas 0,93. Instrumen keseimbangan dinamis menggunakan modified bass test dengan validitas 0,46 dan reliabilitas 0,75 . Teknik analisis data menggunakan uji-t.

Hasil penelitian menunjukkan bahwa ada peningkatan kekuatan togok dan keseimbangan dinamis setelah atlet mengikuti program latihan core stability exercise. Hal ini ditunjukkan dengan hasil paired sample t-test kekuatan togok dan keseimbangan dinamis nilai probabilitasnya adalah $\mathrm{p}=0.025$ dan $\mathrm{p}=0.018$, yang berarti $<$ dari 0.05 . Berdasarkan hasil penelitian dapat disimpulkan bahwa terdapat pengaruh perlakuan core stability exercise terhadap peningkatan kekuatan togok dan keseimbangan dinamis yang bermakna pada atlet UKM Pencak Silat UNY.

Kata kunci: kekuatan togok, keseimbangan dinamis, core stability exercise

Pencak silat merupakan salah satu olahraga body contact yang berasal dari Indonesia. Teknikteknik yang digunakan sangat beranekaragam, seperti teknik pukulan, tendangan, dan bantingan atau kombinasi dari semuanya. Seorang atlet pencak silat harus memiliki keterampilan kompleks yang didukung dengan kondisi fisik yang bagus. Seperti yang disampaikan Hariono (2011: 2) bahwa pencak silat merupakan olahraga yang memerlukan keterampilan yang kompleks, untuk itu diperlukan kondisi fisik yang baik. Atlet pencak silat melakukan gerakan yang cepat dan kuat, sehingga tubuh harus bisa dikendalikan dengan baik agar tidak melakukan kesalahan gerak. Salah satu komponen yang harus dioptimalkan adalah kekuatan togok dan keseimbangan dinamis dari seorang pesilat. Gerakan pencak silat tidak lepas dari hal tersebut. Pesilat yang mempunyai kekuatan yang baik dapat melakukan gerakan lebih baik karena bisa mengontrol setiap gerakan yang dilakukan dan dapat terhindar dari risiko terjadinya cedera. Seperti yang disampaikan Hariono (2006: 54), latihan kekuatan dapat meningkatkan kemampuan otot dan jaringan, mengurangi dan menghindari terjadinya cedera, meningkatkan prestasi, 
terapi dan rehabilitasi cedera pada otot, dan membantu dalam penguasaan teknik. Keseimbangan juga sangat penting bagi seorang pesilat yang dalam pencak silat lebih dominan pada keseimbangan dinamis.

Keseimbangan berperan penting dalam mencegah terjadinya cedera. Latihan keseimbangan pada atlet telah terbukti dapat menurunkan risiko jatuh dan cedera. Program latihan keseimbangan yang baik dapat menurunkan risiko terjadinya cedera, sehingga atlet dapat menampilkan performa maksimal saat bertandaing. Keseimbangan dapat ditingkatkan dengan melakukan latihan core stabilitation (Ipekoglu, 2018). Salah satu latihan untuk meningkatkan kekuatan togok dan keseimbangan dinamis adalah Core stability exercise. Seperti yang disampaikan Kibler dkk (2006:190), manfaat dari core yang kuat yaitu meningkatkan kekuatan dan keseimbangan, menurunkan cedera punggung, dan memaksimalkan keseimbangan dan gerak dari ekstremitas atas dan bawah. Core exercise juga sering digunakan untuk program pencegahan cedera dan exercise therapy rehabilitasi cedera. Seperti yang disampaikan Akuthota et al (2007:39), core stability exercise digunakan untuk meningkatkan performa dan mencegah cedera serta digunakan untuk exercise therapy penyembuhan low back pain.

Berdasarkan observasi yang dilakukan oleh penulis pada proses latihan di beberapa UKM Pencak Silat yang ada di Yogyakarta, pemahaman pelatih terhadap core stability exercise masih kurang. Kenyataannya di lapangan masih ada pelatih yang belum memberikan latihan core stability exercise secara terprogram. Disamping itu, atlet sering mengalami keluhan sakit di punggung bawah (low back pain) setelah latihan, hal ini bisa disebabkan karena lemahnya otot togok. Core stability exercise mengarah untuk penguatan togok dan keseimbangan atlet, namun karena kurangnya pengetahuan dari pelatih tentang pengaruh dan manfaat dari latihan core stability exercise membuat latihan ini belum digunakan selama proses latihan. Kekuatan togok dan keseimbangan dinamis sangat penting bagi atlet pencak silat, dengan kekuatan togok dan keseimbangan dinamis yang baik dapat mengurangi risiko terjadinya cedera. Salah satu bentuk latihan untuk meningkatkannya adalah dengan latihan core stability exercise, namun pengaruh core stability exercise dalam meningkatkan kekuatan togok dan keseimbangan dinamis pada atlet pencak silat masih belum diketahui. Peneliti berusaha untuk mengetahui pengaruh dari core stability exercise pada atlet UKM pencak silat Universitas Negeri Yogyakarta pada penelitian ini.

Pencak silat merupakan sistem yang terdiri atas sikap (posisi) dan gerak-gerik (pergerakan). Ketika seorang pesilat bergerak saat bertarung, sikap dan gerakannya berubah mengikuti perubahan posisi lawan secara berkelanjutan. Segera setelah menemukan kelemahan pertahanan lawan, pesilat akan mencoba mengalahkan lawan dengan suatu serangan yang cepat. Pengurus Besar Ikatan Pencak Silat Indonesia (PB IPSI) mendefinisikan pencak silat adalah hasil budidaya manusia Indonesia untuk membela atau mempertahankan eksistensi (kemandirian) dan integritas (manunggal) terhadap lingkungan hidup/alam sekitarnya untuk mencapai keselarasan hidup guna meningkatkan iman dan takwa kepada Tuhan Yang Maha Esa (Hisbullah, 2008: 21). Olahraga pencak silat mulai 
dipertandingkan secara resmi di PON VII di Jakarta dengan menampilkan nomor tanding, yang dahulu dikenal dengan istilah wiralaga. Untuk kategori seni, istilah seni dulu dikenal dengan pencak silat seni kemudian menjadi wiragana (seni silat tunggal) putra dan putri, wirasanggha (seni silat berpasangan) putra dan putri serta wiraloka (seni silat beregu). Sekarang lebih dikenal dengan istilah TGR yaitu kependekan dari jurus tunggal, jurus ganda, dan jurus beregu (Lubis dan Wardoyo, 2014: 6-7).

Metode latihan kekuatan dapat ditingkatkan dengan cara pembebanan luar dan pembebanan dalam. Menurut Sukadiyanto (2011: 106), ada beberapa metode latihan untu meningkatkan kekuatan beserta sasarannya yaitu metode latihan kekuatan maksimal, umumnya digunakan untuk olahraga yang bersifat body contact, angkat berat, nomor-nomor lempar dan lompat pada olahraga atletik.

1. Metode isometrik dilakukan dengan cara melawan benda atau tahanan dalam keadaan diam, disebut juga metode latihan kekuatan statis. Sasaran latihan ini adalah kelompok otot togok, punggung, lengan, dan bahu. Latihan ini dapat meningkatkan kekuatan maksimal otot dan program rehabilitasi karena cedera.

2. Metode isotonik meningkatkan ketegangan otot pada saat otot dalam keadaan memanjang dan atau dalam keadaan memendek. Kontraksi isotonik melibatkan gerak persendian dan anggota badan (bersifat dinamis). Ada dua tipe kontraksi otot isotonik, yaitu kontraksi eccentric dan concentric. Eccentric adalah kontraksi pada saat otot memanjang, sedangkan concentric adalah kontraksi pada saat otot memendek.

3. Metode isokinetik kontraksi otot yang terjadi secara terus-menerus pada saat otot dalam keadaan memendek dan memanjang sepanjang luas gerak persendian. Metode latihan ini merupakan gabungan dari kontraksi otot isometrik dan isotonik secara terus menerus.

4. Metode sirkuit terdiri atas beberapa item (macam) latihan yang harus dilakukan dalam waktu tertentu. Sasaran latihan ini adalah untuk meningkatkan kekuatan, ketahanan, kecepatan, power, dan kelentukan.

Berdasarkan penjelasan dari ahli di atas dapat ditarik kesimpulan bahwa terdapat lima metode latihan kekuatan, yaitu metode latihan kekuatan maksimal, metode isometrik, metode isotonik, metode isokinetik, dan metode sirkuit. Metode latihan yang digunakan untuk meningkatkan kelompok otot togok adalah metode isometrik.

\section{Peranan Kekuatan dalam Pencak Silat}

Kekuatan harus diberikan kepada pesilat sebagai pondasi dalam membentuk biomotor lain. Seperti yang disampaikan Hariono (2006: 54), kekuatan merupakan komponen biomotor yang penting dan sangat diperlukan untuk meningkatkan daya tahan otot pesilat, melalui latihan kekuatan yang benar akan berpengaruh terhadap komponen biomotor lain. Menurut Nugroho (2001: 94), kekuatan merupakan dasar dari latihan fisik untuk pengembangan latihan power selanjutnya. Menurut Hariono (2006: 54), latihan kekuatan dapat meningkatkan kemampuan otot dan jaringan, mengurangi dan 
menghindari terjadinya cedera, meningkatkan prestasi, terapi dan rehabilitasi cedera pada otot, dan membantu dalam penguasaan teknik. Menurut Nugroho (2001: 93), manfaat latihan kekuatan bagi pesilat adalah mempermudah untuk mempelajari teknik-teknik lain, mengurangi terjadinya risiko cedera, dan memberi kepercayaan diri yang kuat.

Berdasarkan definisi para ahli di atas dapat disimpulkan bahwa kekuatan mempunyai peran penting di pencak silat. Kekuatan merupakan komponen biomotor dasar bagi pesilat, dengan latihan kekuatan dapat membantu menguasai teknik lain, meningkatkan prestasi, terhindar dari cedera, dan memberi kepercayaan diri yang kuat.

\section{Keseimbangan}

Keseimbangan adalah kemampuan untuk mempertahankan kesetimbangan tubuh ketika di tempatkan di berbagai posisi. Definisi menurut O'Sullivan dalam perdana (2014: 58), keseimbangan adalah kemampuan untuk mempertahankan pusat gravitasi pada bidang tumpu terutama ketika saat posisi tegak. Selain itu menurut Thomson dalam perdana (2014: 58), keseimbangan adalah kemampuan untuk mempertahankan tubuh dalam posisi kesetimbangan maupun dalam keadaan statik atau dinamik, serta menggunakan aktivitas otot yang minimal. Menurut Kisner dan Colby (2007: 251), Keseimbangan adalah kemampuan untuk mempertahankan posisi tubuh dalam kesetimbangan. Kesetimbangan berarti bahwa tubuh dalam keadaan diam (keseimbangan statis) atau dalam keadaan bergerak (keseimbangan dinamis). Keseimbangan akan didapat ketika tubuh menempati center of mass (COM) atau center of gravity (COG) dan dipertahankan di atas base of support (BOS).

a. Center of mass (COM) merupakan titik yang sesuai dengan pusat masa tubuh dan merupakan titik pada ssat tubuh berada dalam keseimbangan sempurna.

b. Center of gravity (COG) mengacu pada proyeksi vertikal dari pusat massa ke tanah. Dalam posisi anatomis, COG pada orang dewasa kebanyakan terletak sedikit ke depan pada vertebra sakral kedua atau sekitar 55\% tinggi badan seseorang.

c. Base of support (BOS) merupakan area kontak antara tubuh dan permukaan tumpuan. Penempatan kaki dapat mengubah BOS dan mengubah stabilitas seseorang. Berdiri dengan kaki lebar seperti kebanyakan orang lanjut usia, itu dapat meningkatkan keseimbangan, sedangkan bidang tumpu yang sempit seperti berjalan kaki, dapat mengurangi keseimbangan.

Berdasarkan definisi di atas dapat disimpulkan bahwa keseimbangan adalah kemampuan untuk menjaga tubuh agar tetap seimbang dalam keadaan statik atau dinamik. Keseimbangan akan didapat ketika tubuh menempati center of mass (COM) atau center of gravity (COG) dan dipertahankan di atas base of support (BOS). Menurut Perdana (2014: 58), keseimbangan dibagi menjadi dua, yaitu: (1) keseimbangan statis adalah mempertahankan sikap pada posisi diam di tempat. Ruang gerak biasanya sangat kecil, seperti berdiri di atas alas yang sempit, (2) keseimbangan dinamis adalah kemampuan seseorang untuk mempertahankan posisi tubuh pada waktu bergerak. Seperti sepatu roda, ski air, dan olahraga sejenisnya. Menurut Bronstein, dkk (2004: 386), (1) keseimbangan statis adalah 
keadaan pada saat tubuh tetap diam dalam posisi atau orientasi yang diinginkan, (2) keseimbangan dinamis merupakan keadaan yang memungkinkan tubuh dapat bergerak secara terkendali. Menurut Kisner dan Colby (2007: 251), keseimbangan dinamis merupakan kemampuan untuk mempertahankan tubuh walaupun dalam keadaan bergerak.

Berdasarkan definisi di atas dapat ditarik kesimpulan bahwa keseimbangan dinamis merupakan kemampuan untuk mempertahankan tubuh secara terkendali walaupun dalam keadaan bergerak.

\section{Peranan Keseimbangan dalam Pencak Silat}

Menurut Nugroho (2001: 102), keseimbangan merupakan salah satu komponen penting yang harus dikuasai pesilat, bahwa seorang pesilat harus mampu mempertahankan keseimbangan badan dalam berbagai keadaan agar tetap seimbang. Manfaat latihan keseimbangan bagi pesilat adalah kesadaran akan gerak, dapat mencegah terjadinya cedera, mempermudah melatih teknik, dan melatih ketangkasan gerak. Seorang pesilat harus mampu mempunyai keseimbangan yang baik, hal ini disebabkan oleh: (1) teknik-teknik tendangan selalu mengangkat satu kaki, hal ini menyebabkan keadaan badan menjadi labil, (2) teknik belaan tangkapan selalu mengarah satu tungkai kaki lawan, (3) semua teknik jatuhan selalu mengarah tungkai lawan yang labil (Nugroho, 2001: 102-103).

Berdasarkan pendapat ahli di atas dapat disimpulkan bahwa keseimbangan berperan penting di pencak silat. Latihan keseimbangan dapat mencegah terjadinya cedera, mempermudah melatih teknik, dan melatih ketangkasan gerak

\section{Core Stability Exercise}

Core merupakan kelompok otot batang tubuh yang mengelilingi tulang belakang dan perut. Abdominal, gluteal, hip girdle, paraspinal, dan otot lainnya bekerja sama untuk memberikan stabilitas tulang belakang. Core stability merupakan kontrol motorik yang penting untuk inisiasi gerakan badan sesuai dengan kebutuhan saat beraktivitas. Core stability sangat penting untuk keseimbangan tulang belakang, panggul, dan rantai kinetik. Sport medicine menggunakan core stability exercise untuk meningkatkan performa dan mencegah cedera serta digunakan untuk exercise therapy penyembuhan low back pain (Akuthota dkk 2007: 39).

Menurut Kibler, dkk (2006: 189), core stability merupakan kemampuan untuk mengendalikan posisi dan gerak batang tubuh untuk menghasilkan gerak yang optimal didalam aktivitas. Core stability menjadi komponen penting untuk memaksimalkan fungsi atletik secara efisien. Aktivitas otot core merupakan integrasi dari otot lokal, singlejoint muscle dan multi-joint muscle untuk memberikan stabilitas dan menghasilkan gerakan. Otot core mencakup otot-otot batang tubuh dan panggul yang bertanggung jawab untuk menjaga stabilitas tulang belakang dan panggul serta membantu perpindahan energi dari bagian tubuh besar ke kecil selama beraktivitas.

Berdasarkan definisi para ahli di atas dapat ditarik kesimpulan bahwa core stability exercise adalah latihan untuk meningkatkan kelompok otot batang tubuh yang mengelilingi tulang belakang dan 
perut agar dapat mengendalikan posisi dan gerak batang tubuh untuk menghasilkan gerak yang optimal saat beraktivitas.

\section{Manfaat Core Stability Exercise}

Menurut Akuthota dkk (2008: 39), Manfaat dari core stability exercise yaitu: (1) meningkatkan performa, (2) mencegah terjadinya cedera, (3) mengurangi low back pain. Menurut Kibler, dkk (2006: 190), manfaat core yang kuat yaitu: (1) meningkatkan kekuatan dan keseimbangan, (2) menurunkan cedera punggung, (3) memaksimalkan keseimbangan dan gerak dari ekstremitas atas dan bawah. Menurut Thompson (2008: 182), manfaat yang diperoleh dari core stability exercise adalah: (1) mengurangi risiko cedera, (2) program rehabilitasi cedera, (3) menstabilkan tulang belakang, (4) meningkatkan prestasi atlet.

Berdasarkan pendapat para ahli di atas dapat disimpulkan bahwa manfaat latihan core stability exercise adalah meningkatkan performa, mencegah terjadinya cedera, mengurangi low back pain, meningkatkan kekuatan dan keseimbangan, menurunkan cedera punggung, memaksimalkan keseimbangan dan gerak dari ekstremitas atas dan bawah, mengurangi risiko cedera, program rehabilitasi cedera, menstabilkan tulang belakang, dan meningkatkan prestasi atlet.

\section{METODE PENELITIAN}

\section{Desain Penelitian}

Penelitian ini merupakan penelitian pre-experimental dengan rancangan one group pretestposttest design. One group pretest-posttest merupakan rancangan penelitian yang terdiri atas satu kelompok (tidak ada kelompok kontrol), sedangkan proses penelitiannya dilaksanakan dalam tiga tahap. Pertama, melaksanakan pretest untuk mengukur kekuatan togok dan keseimbangan dinamis responsden sebelum diberikan perlakuan. Kedua, memberikan perlakuan berupa latihan core stability exercise yang terdiri atas lima bentuk latihan. Perlakuan diberikan selama 16 kali pertemuan dengan frekuensi tiga kali per minggu, dilakukan sebanyak tiga set dan dengan durasi 20 detik untuk tiap bentuk latihan. Ketiga, melakukan posttest untuk mengetahui kekuatan togok dan keseimbangan dinamis sesudah diberikan perlakuan.

\section{Populasi dan Sampel Penelitian}

Populasi yang digunakan dalam penelitian ini adalah atlet UKM Pencak silat Universitas Negeri Yogyakarta yang berjumlah 40 orang.

\section{Instrumen dan Teknik Pengumpulan data}

Instrumen yang digunakan dalam penelitian ini adalah back dynamometer untuk mengukur kekuatan togok dan modified bass test untuk mengukur keseimbangan dinamis. Sampel melakukan dua kali pengulangan dan diambil skor yang tertinggi. 
1. Instrumen Tes Kekuatan Togok. Tujuan instrumen ini adalah untuk mengukur kekuatan otot punggung dalam satuan $\mathrm{kg}$ dengan tingkat ketelitian $0.5 \mathrm{~kg}$. Alat dan bahan: back and leg dynamometer.

2. Instrumen Tes Keseimbangan Dinamis

Tujuan instrumen ini adalah untuk mengukur keseimbangan dinamis selama bergerak dan sesudah bergerak. Alat dan bahan: stopwatch, 3/4-inc selotip, dan meteran. Cara melakukan:

a. Berdiri satu kaki dengan kaki kanan sebagai tumpuan.

b. Kemudian melompat ke tanda nomor 1 dengan kaki kiri sebagai tumpuan dan langsung dalam posisi diam atau statis (tidak bergerak selama 5 detik).

c. Setelah itu melompat ke tanda nomor 2 dengan kaki kanan sebagai tumpuan dan langsung dalam posisi diam atau statis (tidak bergerak selama 5 detik).

d. Dengan cara yang sama, melompat mengikuti tanda yang telah diberi nomor sesuai urutan sampai tanda nomor 10 .

e. Dari tanda nomor 1-10 pastikan setiap lompatan mendarat dengan satu kaki yang berlawanan. Dimulai dengan mendarat dengan kaki kiri di tanda pertama, selanjutnya kaki kanan di tanda kedua dan seterusnya sampai tanda kesepuluh dengan salah satu kaki bergantian.

f. Sampel melompat menginjak tanda, telapak kaki harus menutup setiap tanda sehingga tanda tidak dapat dilihat.

\section{Perlakuan/ Treatment}

Perlakuan diberikan selama 16 kali pertemuan dengan frekuensi 3 kali per minggu. Dilakukan selama 3 set dengan waktu 20 detik untuk tiap bentuk latihan, serta dilakukan peningkatan waktu 5 detik setiap 4 pertemuan. Waktu recovery yang diberikan 20-40 detik dengan interval tiap set 25 menit. Gerakan yang dilakukan di antaranya Front Plank, Side Plank, Superman, Crunch, Double-Leg Lowering With Bent Knees.

\section{HASIL PENELITIAN DAN PEMBAHASAN}

a. Kekuatan Togok

Deskripsi rata-rata kekuatan togok subjek disajikan dalam Gambar.1 di bawah ini:

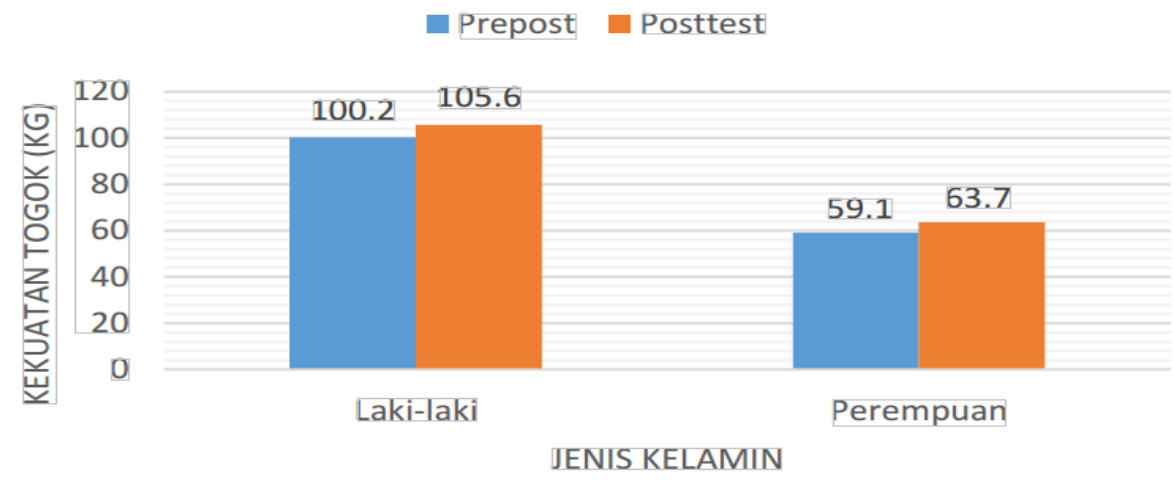

Gambar 1. Rata-Rata Kekuatan Togok 
Berdasarkan gambar di atas dapat diketahui bahwa nilai rata- rata prepost kekuatan togok lakilaki adalah 100,2 dan nilai rata-rata posttest adalah 105,6. Nilai rata-rata pretest kekuatan togok perempuan adalah 59,1 dan nilai rata-rata posttest adalah 63,7 .

Keseimbangan Dinamis

Deskripsi rata-rata keseimbangan dinamis subjek disajikan dalam Gambar.2 di bawah ini:

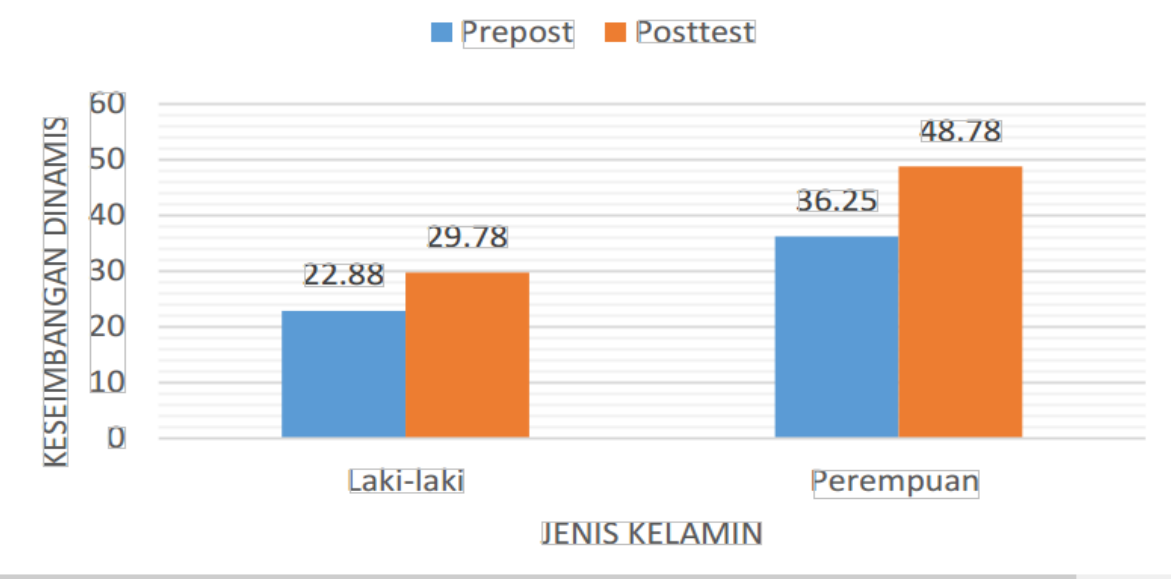

Gambar 2. Rata-Rata Keseimbangan Dinamis

Berdasarkan gambar di atas dapat diketahui bahwa nilai ratarata prepost keseimbangan dinamis laki laki adalah 22,88 dan nilai rata-rata posttest adalah 29,78 . Nilai rata-rata pretest keseimbangan dinamis perempuan adalah 36,25 dan nilai rata-rata posttest adalah 48,78 . Data penelitian ini didapat dari hasil pretest dan posttest dengan pemberian perlakuan latihan core stability exercise. Tes awal (pretest) ini diambil untuk mengetahui kekuatan togok dan keseimbangan dinamis sebelum diberikan perlakuan. Setelah diberikan perlakuan berupa latihan core stability exercise, pada tahap selanjutnya akan dilakukan tes akhir (posttest). Posttest bertujuan untuk mengetahui pengaruh perlakuan yang telah diberikan selama latihan. Adapun cara yang dilakukan untuk mengukur kekuatan togok dengan menggunakan alat ukur back dynamometer. ntuk mengukur keseimbangan dinamis digunakan alat ukur modified bass test.

\section{Uji Normalitas}

Uji normalitas dimaksudkan untuk mengetahui apakah data dalam penelitian mempunyai sebaran distribusi normal atau tidak. Penghitungan uji normalitas ini menggunakan rumus Shapiro-Wilk, dengan pengolahan menggunakan bantuan komputer program SPSS 22. Kemudian apabila pada output dilihat nilai probabilitasnya $>0.05$, data berdistribusi normal. Hasil analisis dapat dilihat di bawah ini:

1. Uji Normalitas Kekuatan Togok

Berdasarkan hasil output di atas, dapat disimpulkan bahwa data pretest dan posttest kekuatan togok nilai probabilitasnya adalah 0.167 dan 0.272 , yang berarti $>$ dari 0.05 . Jadi data pretest dan posttest kekuatan togok berdistribusi normal dan layak untuk diolah menggunakan uji-t. 


\section{Uji Normalitas Kekuatan Togok}

Tabel 8. Uji Normalitas Kekuatan Togok

\begin{tabular}{|l|r|r|r|}
\hline & \multicolumn{3}{|c|}{ Shapiro-Wilk } \\
\cline { 2 - 4 } & \multicolumn{1}{|c|}{ Statistic } & \multicolumn{1}{c|}{ of } & \multicolumn{1}{c|}{ Sig. } \\
\hline PRETEST & .932 & 20 & .167 \\
POSTEST & .943 & 20 & .272 \\
\hline
\end{tabular}

a. Lilliefors Significance Correction

Uji Normalitas Keseimbangan Dinamis

Uji normalitas keseimbangan dinamis berdasarkan hasil output di atas, dapat disimpulkan bahwa data pretest dan posttest keseimbangan dinamis nilai probabilitasnya adalah 0.138 dan 0.120 , yang berarti $>$ dari 0.05 . Jadi data pretest dan posttest keseimbangan dinamis berdistribusi normal dan layak untuk diolah menggunakan uji-t.

Tabel 9. Uji Normalitas Keseimbangan Dinamis

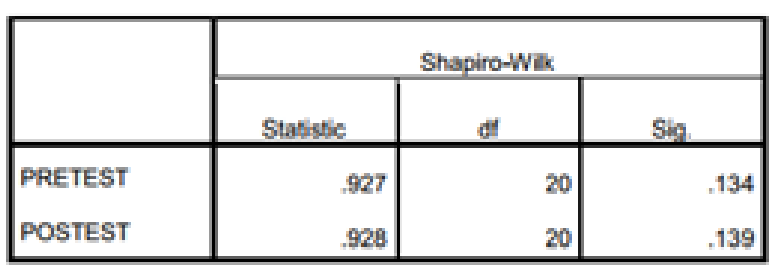

Setelah diketahui hasil uji normalitas dan mendapatkan hasil data berdistribusi normal, dilakukan paired sample t-test. Hal ini dilakukan untuk mengetahui kemaknaan dari perlakuan core stability exercise terhadap peningkatan kekuatan togok dan keseimbangan dinamis atlet UKM Pencak Silat UNY.

1. Kekuatan Togok

Tabel 10. Paired Sample t test Kekuatan Togok

Paired Samples Test

\begin{tabular}{|c|c|c|c|c|c|c|c|c|c|}
\hline & & \multicolumn{5}{|c|}{ Paired Differences } & \multirow[b]{3}{*}{$t$} & \multirow[b]{3}{*}{ df } & \multirow{3}{*}{$\begin{array}{l}\text { Sig. (2- } \\
\text { tailed) }\end{array}$} \\
\hline & & \multirow{2}{*}{$\begin{array}{c}\text { Mea } \\
\mathrm{n} \\
\end{array}$} & \multirow{2}{*}{$\begin{array}{c}\text { Std. } \\
\text { Deviatio } \\
\mathrm{n} \\
\end{array}$} & \multirow{2}{*}{$\begin{array}{l}\text { Std. } \\
\text { Error } \\
\text { Mean } \\
\end{array}$} & \multicolumn{2}{|c|}{$\begin{array}{c}95 \% \text { Confidence } \\
\text { Interval of the } \\
\text { Difference }\end{array}$} & & & \\
\hline & & & & & Lower & Upper & & & \\
\hline $\begin{array}{l}\text { Pair } \\
1\end{array}$ & $\begin{array}{l}\text { PRETEST - } \\
\text { POSTEST }\end{array}$ & $\begin{array}{r}- \\
5.00 \\
000\end{array}$ & 9.20526 & 2.05836 & 9.30820 & -69180 & 2.429 & 19 & .025 \\
\hline
\end{tabular}


Uji Hipotesis

Data yang diperoleh berdasarkan hasil pengukuran saat pretest dan posttest. Data pretest dan posttest kekuatan togok dapat dianalisis dengan menggunakan program SPSS versi 22. Berdasarkan hasil output di atas, dapat disimpulkan bahwa hasil paired sample t-test kekuatan togok nilai $\mathrm{p}=$ 0.025 , yang berarti $<$ dari 0.05 . Hal ini berarti hasil hipotesis dapat diterima dengan kesimpulan bahwa terdapat pengaruh perlakuan core stability exercise terhadap peningkatan kekuatan togok yang bermakna pada atlet UKM Pencak Silat UNY.

\section{Keseimbangan Dinamis}

Data yang diperoleh berdasarakan dari hasil pengukuran saat pretest dan posttest. Data pretest dan posttest keseimbangan dinamis dapat dianalisis dengan menggunakan program SPSS versi 22. Hasil analis dapat dilihat pada Tabel 11.

Tabel 11. Paired Sample t test Keseimbangan Dinamis

Paired Samples Test

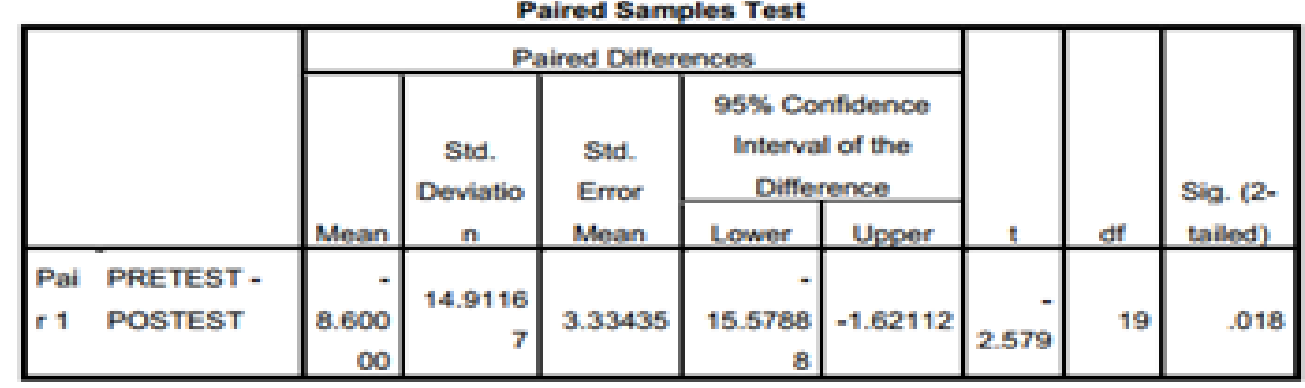

Berdasarkan hasil output di atas, dapat disimpulkan bahwa hasil paired sample t-test keseimbangan dinamis nilai $\mathrm{p}=0.018$, yang berarti $<$ dari 0.05 . Hal ini berarti hasil hipotesis dapat diterima dengan kesimpulam bahwa terdapat pengaruh perlakuan core stability exercise terhadap peningkatan keseimbangan dinamis yang bermakna pada atlet UKM pencak silat UNY.

\section{Pembahasan}

Berdasarkan hasil penelitian yang didapat, bahwa treatment core stability exercise terbukti mampu meningkatkan kekuatan togok dan keseimbangan dinamis atlet pencak silat di UKM Pencak Silat UNY. Treatment diberikan selama 16 kali pertemuan dengan frekuensi 3 kali per minggu. Latihan core stability exercise dilakukan sebanyak 3 set. Terdapat 5 bentuk latihan core stability exercise dengan durasi 20 detik untuk setiap bentuk latihan, serta dilakukan peningkatan waktu 5 detik setiap 4 pertemuan. Core merupakan kelompok otot batang tubuh yang mengelilingi tulang belakang dan perut. Bliven dan Anderson (2013: 514) menyatakan bahwa otot-otot core terdiri dari diaphragm (superior), abdominal and oblique muscles (anterior-lateral), paraspinal and gluteal muscles (posterior), and pelvic floor and hip girdle (inferior). Menurut Contreas (2014: 82), otot core diklasifikasikan menjadi otot bagian dalam dan bagian luar. Otot bagian luar terdiri atas otot-otot besar seperti rectus abdominis, 
internal and external obliques, erector spinae, gluteus maximus, latissimus dorsi, quadratus lumborum, dan psoas. Otot-otot ini yang bertugas menghasilkan dan menahan gerakan. Otot-otot core bagian dalam, membentuk silinder yang berkontraksi sesaat, sebelum, dan selama melakukan gerakan untuk melindungi tulang belakang. Otot bagian dalam terdiri dari multifidus di belakang, transversus abdominis di bagian depan dan samping, diafragma di bagian atas, dan otot dasar panggul di bagian bawah.

Latihan core stability exercise dalam penelitian ini terdiri dari 5 bentuk latihan, yaitu plank, side plank, crunch, superman, dan double-leg lowering with bent knee. Kekuatan togok dapat ditingkatkan melalui latihan tersebut. Hal itu disebabkan oleh 5 bentuk latihan telah meningkatkan otot-otot disekitar togok. Plank meningkatkan otot disekitar daerah perut (Rectus abdominis, internal oblique, external oblique), pantat (gluteus maximus), dan quadriceps. Side plank lebih dominan pada meningkatkan otot perut bagian samping, yaitu: External oblique, internal oblique. Latihan ini juga meningkatkan otot gluteus medius dan quadratus lumborum. Superman lebih berfokus untuk meningkatkan otot core bagian belakang, yaitu gluteus maximus, erector spinae (spinalis, longissimus, iliocostalis) dan juga otot hamstrings (biceps femoris, semitendinosus, semimembranosus). Latihan crunch meningkatkan otot perut bagian depan, yaitu Rectus abdominis. External oblique, dan internal oblique juga mengalami peningkatan apabila melakukan latihan ini. Double-leg lowering with bent knees meningkatkan otot lower rectus abdominis, psoas major, dan rectus femoris.

\section{KESIMPULAN}

Penelitian ini juga membuktikan latihan core stability exercise dapat meningkatkan keseimbangan dinamis atlet. Keseimbangan dinamis merupakan keadaan atlet dapat bergerak secara terkendali dan dapat mempertahankan keseimbangan tubuh dalam keadaan apa pun. Keseimbangan merupakan salah satu komponen penting yang harus dikuasai pesilat, seorang pesilat harus mampu mempertahankan keseimbangan badan dalam berbagai keadaan agar tetap seimbang. Salah satu faktor yang memengaruhi keseimbangan adalah kekuatan otot. Kontrol keseimbangan paling dipengaruhi oleh kekuatan otot panggul. Seperti yang disampaikan Bronstein dkk (2004: 15), keseimbangan dikendalikan oleh otot-otot panggul, sementara ketika ada gangguan keseimbangan dikontrol oleh responss pada otot pergelangan kaki. Kunci dari keseimbangan ketika bergerak adalah kontrol masa kepala, lengan, dan togok. Keseimbangan dinamis dari kepala, lengan, dan togok dikendalikan oleh otot-otot panggul. Latihan core stability exercise meningkatkan otot-otot panggul, sehingga keseimbangan dinamis atlet dapat meningkat.

Core stability exercise merupakan salah satu latihan yang harus dilakukan atlet, karena berpengaruh terhadap peningkatan kekuatan togok secara signifikan. Core menjadi salah satu komponen yang harus dimaksimalkan pesilat untuk meningkatkan performa sehingga dapat terhindar dari cedera. Core merupakan kelompok otot yang berperan untuk memberikan stabilitas tulang 
belakang. Seperti yang disampaikan Akuthota dkk (2007: 39), core stability sangat penting untuk keseimbangan tulang belakang, panggul, dan rantai kinetik. Sedangkan sport medicine menggunakan core stability exercise untuk meningkatkan performa dan mencegah cedera serta digunakan untuk exercise therapy penyembuhan lowback pain. Menurut Kibler, dkk (2006: 190), manfaat core yang kuat dapat meningkatkan kekuatan dan keseimbangan, menurunkan risiko cedera punggung, dan dapat memaksimalkan keseimbangan dan gerak dari ekstremitas atas dan bawah. Sedangkan menurut Thompson (2008: 182), manfaat yang diperoleh dari core stability exercise adalah dapat mengurangi risiko cedera, dapat digunakan untuk program rehabilitasi cedera, dapat menstabilkan tulang belakang, dan meningkatkan prestasi atlet. Atlet yang mempunyai kekuatan togok dan keseimbangan dinamis yang bagus dapat membantu atlet meraih prestasi. Togok dan keseimbangan merupakan komponen yang harus dimaksimalkan oleh atlet silat, karena gerakan-gerakan pencak silat tak lepas dari hal tersebut. Kekuatan dan keseimbangan yang bagus dapat memberi kepercayaan diri yang kuat, kesadaran akan gerak, dapat mencegah terjadinya cedera, mempermudah melatih teknik, dan melatih ketangkasan gerak. Hasil penelitian berimplikasi bahwa latihan core stability exercise dapat digunakan untuk membantu atlet pada umumnya dan atlet silat khususnya untuk meningkatkan kekuatan togok dan keseimbangan dinamis sehingga dapat membantu mencapai puncak prestasi. Selain itu latihan core stability exercise juga bisa dijadikan program pelatih untuk pencegahan cedera pada atlet

\section{DAFTAR PUSTAKA}

Akhutota, V., Ferreiro, A., Moore, T., et al. (2008). Core Stability Exercise Principle. Current Sports Medicine Report. Vol 7, No. 1, pp.39-44

Almy, A. M. (2014). Kontribusi Kecepatan Reaksi Kaki, Daya Ledak Otot Tungkai dan Keseimbangan Terhadap Kemampuan Lari 100 Meter. Wahana Didaktika Vol. 12 No. 3 September 2014: 1-18.

Bliven \& Anderson. (2013). Core Stability Training for Injury Prevention. SPORTS HEALTH. vol. 5 • no. 6.

Bronstein, A. M., Brant, T., Nutt, J.G., et al. (2004). Clinical Disorder of Balance, Posture, and Gait (2nded). London: ARNOLD.

Contreras, B. (2014). Body Weight Strenght Training Anatomy. United Stade: Human Kinetic.

Hariono, A. (2006). Metode Melatih Fisik Pencak Silat. Diktat. Yogyakarta: Universitas Negeri Yogyakarta.http://file.upi.edu/Direktori/FPOK/JUR._PEND._OLAHRAGA/196506141990011YUN YUN_YUDIANA/Latihan_Kondisi_Fisik.pdf di akses pada 16 Juli 2017

Kibler, W. B., Press, J. \& Sciascia, A. (2006). The Role of Core Stability in Athletic Function. Sports Med 2006; 36 (3): 189-198.

Kisner, C. \& Colby, L.A. (5th) Therapeutic Exercise. Philadelphia: F.A.DAVIS COMPANY.

Kriswanto. (2015). Pencak Silat: Sejarah dan Perkembangan Pencak Silat, Teknik-Teknik dalam Pencak Silat, Pengetahuan Dasar Pertandingan Pencak Silat. Yogyakarta: PUSTAKABARUPRESS.

Lubis \& Wardoyo. (2014). Pencak Silat, Edisi Kedua. Jakarta: PT Raja Grafindo Persada.

Nugroho, A. (2001). Pedoman Latihan Pencak Silat. Diktat. Yogyakarta: Universitas Negeri Yogyakarta. 
Susanto, D. (2014). Pengaruh Core Stability Terhadap Peningkatan Keseimbangan Dinamik pada Resimen Mahasiswa Universitas Muhammadiyah Surakarta. 2014. Naskah Publikasi. Surakarta: UMS.

Tantawi, S. (2011). Effect of Core Stability Training on Some Physical Variables and the Performance Level of the Compulsory Kata for Karate Players. World Journal of Sport Sciences 5 (4): 288-296, 2011.

Thompson, K.G. Optimizing Performance by Improving Core Stability and Core Strength. Sports Med. 2008;38 (12):995-1008

Widiastuti. (2011). Tes dan Pengukuran Olahraga. Jakarta: PT Bumi Timur Jaya. 